Information for Authors

Avis aux auteurs
The purpose of the Canadian Journal of Philosophy is the publication in Canada of philosophical work of high quality, in English or French, and in any field of philosophy. All submissions are given blind editorial review; those of departmental colleagues are externally refereed.

Four copies of submitted manuscripts, double-sided if preferred, should be sent to: Executive Secretary, Canadian Journal of Philosophy, University of Lethbridge, Lethbridge, Alberta, Canada T1K 3M4. It is preferred that manuscripts be typed double-spaced, including quotes and footnotes. In general, the Canadian Journal of Philosophy follows The University of Chicago Marual of Style. Footnotes should be numbered consecutively and assembled on separate pages at the end of the manuscript. Manuscripts should be prepared for blind review, which means they should contain no self-identifying references in either text or footnotes. Manuscripts will not be returned unless return postage is prepaid by cheque, money-order, reply coupons, or Canadian stamps.

Authors will receive, without charge, 25 copies of their articles. Additional offprints may be ordered when the proofs are returned to the publisher.

The articles in CJP are indexed in The Philosophers' Index, Bowling Green, Ohio, USA, the Répertoire bibliographique de la philosophie, Louvain, Belgium, The Modern Language Association Directory of Periodicals, the Humanities Index, the International Bibliography of the Social Sciences, and the Canadian Periodical Index.

All enquiries of an editorial nature should be directed to the Executive Secretary at the above address.

The Canadian Journal of Philosophy a pour objet la publication canadienne, en langues anglaise ou française, d'études philosophiques de haut niveau, quel que soit le domaine philosophique auxquelles elles appartiennent. Les communications sont évaluées dans l'anonymat de leurs auteurs; celles que soumettent les collègues départementaux sont référées à un comité de lecture extérieur.

Les manuscrits, en quatre exemplaires, doivent être adressés à La Secrétaire à la Rédaction. Canadian Journal of Philosophy, University of Lethbridge, Lethbridge, Alberta, Canada T1K 3M4. Soumettre de préférence des manuscrits (citations et notes comprises) dactylographiés à double interligne, en prenant pour guide, dans la mesure du possible, The University of Chicago Manual of Style. Les notes doivent suivre la numérotation continue et figurer sur des feuilles indépendantes en annexe au manuscrit. Les manuscrits devraient être préparé pour l'évaluation anonyme par les pairs. Il ne doit pas par conséquent contenir aucune référence, que ce soit dans le texte ou dans les notes, qui pourrait servir à identifier l'auteur. Les textes non insérés ne sont rendus qu'en cas de prépaiement des frais de poste par chèque, mandat, coupons-réponse, ou timbres canadiens.

Les auteurs recoivent gratuitement 25 tirés-à part de leur article. Ils sont priés, s'ils désirent en obtenir un plus grand nombre à titre onéreux, en informer l'imprimeur lors de renvoi des épreuves.

Les articles du CIP sont catalogués dans The Philosophers' Index, Bowling Green, Ohio, E-U, le Répertoire bibliographique de la philosophie, Louvain, Belgique, The Modern Language Association Directory of Periodicals, Humanities Index, International Bibliography of the Social Sciences et l'Index de Périodiques Canadiens. 


\section{Subscription Information}

Canadian Journal of Philosophy is published by the University of Calgary Press.

Canadian Journal of Philosophy is published quarterly, in March, June, September, and December. In addition to these regular issues, $C J P$ publishes annually a supplementary volume of original papers on a selected theme of contemporary philosophical interest. This supplementary volume is free to all subscribers to the journal in that year. Supplementary volumes may also be purchased separately from Raincoast Books, 8680 Cambie St., Vancouver, BC V6P 6M9.

Correspondence regarding subscriptions, renewals, and single issues should be addressed to Canadian Journal of Philosophy c/o University of Calgary Press, The University of Calgary, Calgary, Alberta, Canada T2N 1N4.

A subscription for the 1999 volume of four issues plus the supplementary volume is:

$\begin{array}{lrr} & \text { Canada } & \text { Outside Canada } \\ \text { Institutions } & \text { Cdn. } \$ 50.00 & \text { US } \$ 50.00 \\ \text { Individuals } & 25.00 & 25.00 \\ \text { Students } & 15.00 & 15.00 \\ \text { Single issues } & 9.00 & 9.00\end{array}$

A joint subscription to Canadian Journal of Philosophy and the Australasian Journal of Philosophy is available to individuals at $\$ 45$ (US $\$ 40$, outside Canada) and to students at $\$ 25$. Outside Canada the price is in US dollars. Canadian residents please add 7\%GST.

\begin{tabular}{l|} 
Journalian \\
Philosophy \\
University of Calgary Press \\
The University of Calgary \\
CALGARY, Alberta, Canada T2N 1N4 \\
403-220-7736 Fax 403-282-0085 \\
Email: wgee@ucalgary.ca
\end{tabular}

Please send me information on CJP Supplementary Volumes $\square$

Name

Address

City

Country Postal Code

Visa $\square \quad$ Mastercard $\square \quad$ No.

Expiry Date

Cheques should be made payable to University of Calgary Press. 
Abonnements
Canadian Journal of Philosophy est publié par University of Calgary Press.

Canadian Journal of Philosophy est une publication trimestrielle paraissant en mars, juin, septembre, et décembre. Outre ses quatre fascicules réguliers, il publie, annuellement, un supplément thématique d'articles inédits consacrés à des sujets d'actualité philosophique. Le supplément est offert gratuitement à tout abonné de l'année courante. Les suppléments sont également disponibles à titre onéreux à Raincoast Books, 8680 Cambie St., Vancouver, BC V6P 6M9.

Toute correspondance concernant l'administration (abonnements, renouvellements, commandes de numéros) doit être adressée à Canadian Journal of Philosophy, c/o University of Calgary Press, The University of Calgary, Calgary, Alberta, Canada T2N $1 \mathrm{~N} 4$.

Tarifs d'abonnement au volume 1999 (4 fascicules et de suppléments):

$\begin{array}{lrr} & \text { Canada } & \text { Hors-Canada } \\ \text { Institutions } & \text { Cdn. 50,00\$ } & \text { US 50,00\$ } \\ \text { Individus } & 25,00 \$ & 25,00 \$ \\ \text { Etudiants } & 15,00 \$ & 15,00 \$ \\ \text { Numéro simple } & 9,00 \$ & 9,00 \$\end{array}$

Tout individu ou étudiant peut souscrire, à raison de $45 \$$ (hors-Canada, US40\$) et $25 \$$ respectivement, un double abonnement au Canadian Journal of Philosophy et à l'Australasian Journal of Philosophy. Règlement en dollars US pour tous ceux qui résident en dehors du Canada. Les résidents du Canada doivent payé la TPS.

\begin{tabular}{l|l|} 
C. Canadian \\
Journal of \\
PhilosOphy \\
University of Calgary Press \\
The University of Calgary \\
CALGARY, Alberta, Canada T2N 1N4 \\
403-220-7736 Fax 403-282-0085 \\
Email: wgee@ucalgary.ca
\end{tabular}

Veuillez me faire parvenir tous les renseignernents concernant les suppléments du $C J P$

Nom

Adresse

Ville

Pays Code Postal

Visa $\square \quad$ Mastercard $\square \quad$ No.

Date d'expiration

Libeller tout chèque à l'ordre de University of Calgary Press. 


\author{
Other \\ Business \\ Information
}

Automatic
Permission
to Reproduce

Back Issues

Services
administratifs
— détails
supplémen-
taires

Reproduction

affranchie

d'agrément

préalable

\section{Volumes \\ antérieurs}

All business correspondence should be addressed to Canadian Journal of Philosophy, University of Calgary Press, Calgary, Alberta T2N $1 \mathrm{~N} 4$. This includes enquiries concerning advertising and promotion, exchanges, and reprinting. The copyright for all materials appearing in the regular issues and in the supplements of this journal is held by the Canadian Journal of Philosophy, and consent for any reproduction or reprinting must be obtained with the following exception.

Permission to reproduce parts of individual numbers of Canadian Journal of Philosophy by photocopy, xerox, offset, etc., for scholarly purposes (but not for republishing by printing nor for sale to the public) is automatically granted without prior permission being secured at the following rates: first 5 copies, no charge; 5 cents for each copy in excess of five of each page of $C J P$.

Remuneration is to be paid to the Canadian Journal of Philosophy, stating title and author of the article and number of copies. Proceeds above $\$ 10.00$ from any one article will be shared with the author. This announcement applies retroactively to volume I, number 1 .

Canadian Journal of Philosophy is indexed in Canadian Magazine Index by Micromedia Limited.

Toute correspondance administrative, à l'exception de celle qui concerne les abonnements, renouvellements et commandes de numéros et de suppléments, doit être adressée aux Canadian Journal of Philosophy, University of Calgary Press, Calgary, Alberta T2N 1N4. Ecrire à l'adresse ci-dessus pour tous renseignements relatifs à la publicité et à la promotion, ainsi qu'aux échanges et aux réimpressions. Le copyright des articles afférents aux fascicules et suppléments est propriété du Canadian Journal of Philosophy. Leur reproduction ou réimpression en tout ou partie ne peut être faite sans l'agrément préalable de le Directeur de la Publication, sauf dans le cas suivant.

Est affranchie d'agrément préalable la reproduction partielle des numéros du Canadian Journal of Philosophy par procédé technique de photocopie, xerox, offset, etc., lorsqu'elle vise exclusivement à des fins ou à des recherches académiques. Est interdite toute réimpression ayant pour objet la vente au public. Conditions tarifaires de reproduction: $1-5$ copies, accordé à titre gracieux; 6 copies ou en plus, 5 cents pour chaque copie de chaque page du CJP.

Effectuer tout règlement à l'ordre du Canadian Journal of Philosophy. Avoir soin d'indiquer le nom de l'auteur et le titre de l'article à reproduire d'une part, et le nombre de copies requises, de l'autre. Les apports provenant d'un article sont partagés à égalité avec son auteur pour la part numéraire dépassant $\$ 10.00$ (règlement rétroactif au volume I, No. 1).

Canadian Journal of Philosophy est répertoirié par Micromedia ltée dans le Canadian Magazine Index. 


\section{CANADIAN JOURNAL OF PHILOSOPHY SUPPLEMENTARY VOLUMES}

\begin{tabular}{|c|c|c|c|c|}
\hline & & & $\begin{array}{l}\text { Retail } \\
\text { in } \\
\text { Canada } \\
\text { Cdn. } \$ \$\end{array}$ & $\begin{array}{c}\text { Retail } \\
\text { outside } \\
\text { Canada } \\
\text { US } \$ \$\end{array}$ \\
\hline \multirow[t]{2}{*}{ Vol. I } & -1975 & $\begin{array}{l}\text { Part 1: New Essays in the } \\
\text { History of Philosophy }\end{array}$ & 10.00 & 10.00 \\
\hline & & $\begin{array}{l}\text { Part 2: New Essays in the } \\
\text { Philosophy of Mind }\end{array}$ & 10.00 & 10.00 \\
\hline Vol. III & -1977 & New Essays in Contract Theory & 13.00 & 13.00 \\
\hline Vol. IV & -1978 & $\begin{array}{l}\text { New Essays in Rationalism } \\
\text { and Empiricism }\end{array}$ & 13.00 & 13.00 \\
\hline Vol. V & -1979 & $\begin{array}{l}\text { New Essays on Mill and } \\
\text { Utilitarianism }\end{array}$ & 13.00 & 13.00 \\
\hline Vol. VI & -1980 & $\begin{array}{l}\text { New Essays in Philosophy of } \\
\text { Language }\end{array}$ & 13.00 & 13.00 \\
\hline Vol. VII & -1981 & Marx and Morality & 15.00 & 15.00 \\
\hline Vol. VIII & -1982 & $\begin{array}{l}\text { New Essays in Ethics and } \\
\text { Public Policy }\end{array}$ & 14.00 & 13.00 \\
\hline Vol. IX & -1983 & New Essays on Plato & 13.00 & 13.00 \\
\hline Vol. X & -1984 & New Essays on Aristotle & 14,00 & 14.00 \\
\hline Vol. XI & -1985 & $\begin{array}{l}\text { New Essays in the Philosophy } \\
\text { of Mind, Series II }\end{array}$ & 14.00 & 14.00 \\
\hline Vol. XII & -1986 & $\begin{array}{l}\text { Nuclear Weapons, Deterrence } \\
\text { and Disarmament }\end{array}$ & 12.00 & 10.00 \\
\hline Vol. XIII & -1987 & $\begin{array}{l}\text { Science, Morality and } \\
\text { Feminist Theory }\end{array}$ & 14.00 & 12.00 \\
\hline Vol. XIV & -1988 & Philosophy and Biology & 14.00 & 12.00 \\
\hline Vol. XV & -1989 & Analyzing Marxism & 25.00 & 21.00 \\
\hline Vol. XVI & -1990 & $\begin{array}{l}\text { Canadian Philosophers - } \\
\text { Celebrating Twenty Years of the } \\
\text { Canadian Journal of Philosophy }\end{array}$ & 24.00 & 20.00 \\
\hline Vol. XVII & -1991 & $\begin{array}{l}\text { Aristotle and his Medieval } \\
\text { Interpreters }\end{array}$ & 21.00 & 21.00 \\
\hline Vol. XVIII & -1992 & Return of the A Priori & 22.00 & 22.00 \\
\hline Vol. XIX & -1993 & Méta-Philosophie & 30.00 & 30.00 \\
\hline Vol. XX & -1994 & Biology \& Society & 30.00 & 30.00 \\
\hline Vol. XXI & -1995 & On the Relevance of Metaethics & 24.00 & 24.00 \\
\hline Vol. XXII & -1996 & Rethinking Nationalism & 30.00 & 30.00 \\
\hline Vol. XXIII & -1997 & Meaning and Reference & 20.00 & 20.00 \\
\hline
\end{tabular}

Postage and Handling (Canada/U.S.A.) is $\$ 5.00$ (1-3 books). Postage and Handling (outside Canada) is $\$ 9.00$.

Canadian orders must include $7 \%$ GST on the total cost of the book(s) as well as the postage and handling.

Prices outside Canada are in US dollars.

Order University of Calgary Press

From: c/o Raincoast Distribution Services 8680 Cambie Street

Vancouver, BC V6P 6M9
Fax Orders:

1-800-565-3770

Email: custserv@raincoast.com 


\section{UNIVERSITY OF CALGARY PRESS}

\section{Meaning and Reference}

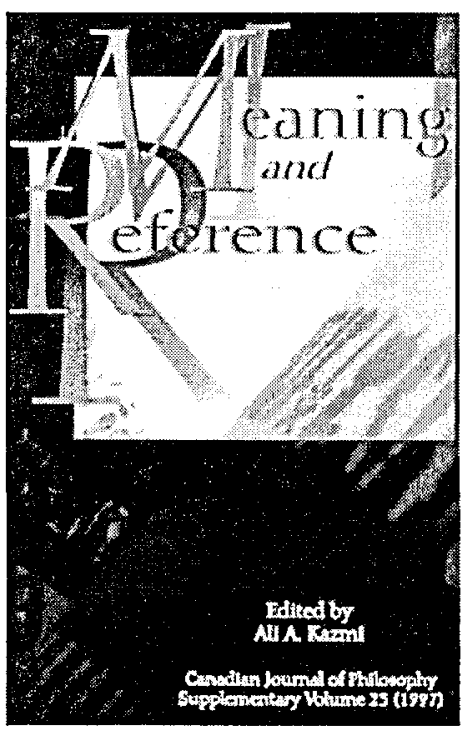

Includes:

Terence Parsons - Missing Modes of Supposition John Burgess - Quinus ab Omni Naevo Vindicatus Richard Cartwright - On Singular Propositions Nathan Salmon - Is de re Belief Reducible to de dicto?

George Wilson - On Some Untamed Anaphora Vann McGee • "Kilimanjaro"

Mark Richard - Inscrutability

Scott Soames - Skepticism about Meaning: Indeterminacy, Normativity, and the Rule-Following Paradox

\section{Kazmi, Ali, editor}

Canadian Journal of Philosophy, Supplementary Volume XXIII (1997)

$\$ 20.00$ (Outside Canada: \$US20.00) ISBN 0-919491-23-5 ISSN 0229-7051 vi +260 pp. biblio, index $5.5 \times 8.5$ in. June 1998

This is a collection of eight new essays by some of the most prominent contemporary philosophers of language. These essays cover a variety of topics including scepticism about meanining and reference, vagueness, rigid designation, de $r e$ belief, pronominal anaphora, Quinean objections to quantified modal logic, and supposition. This volume will be of interest to anyone who works in the philosophy of language and philosophical logic.

Ali Kazmi is an editor of the Canadian Journal of Pbilosopby and an associate professor of philosophy at the University of Calgary.

\section{Order from Raincoast Distribution Services 8680 Cambie Street, Vancouver BC V6P 6M9 \\ Telephone: 1-800-663-5714 \\ Fax: 1-800-565-3770 \\ E-mail: custserv@raincoast.com}

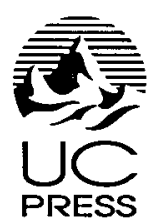




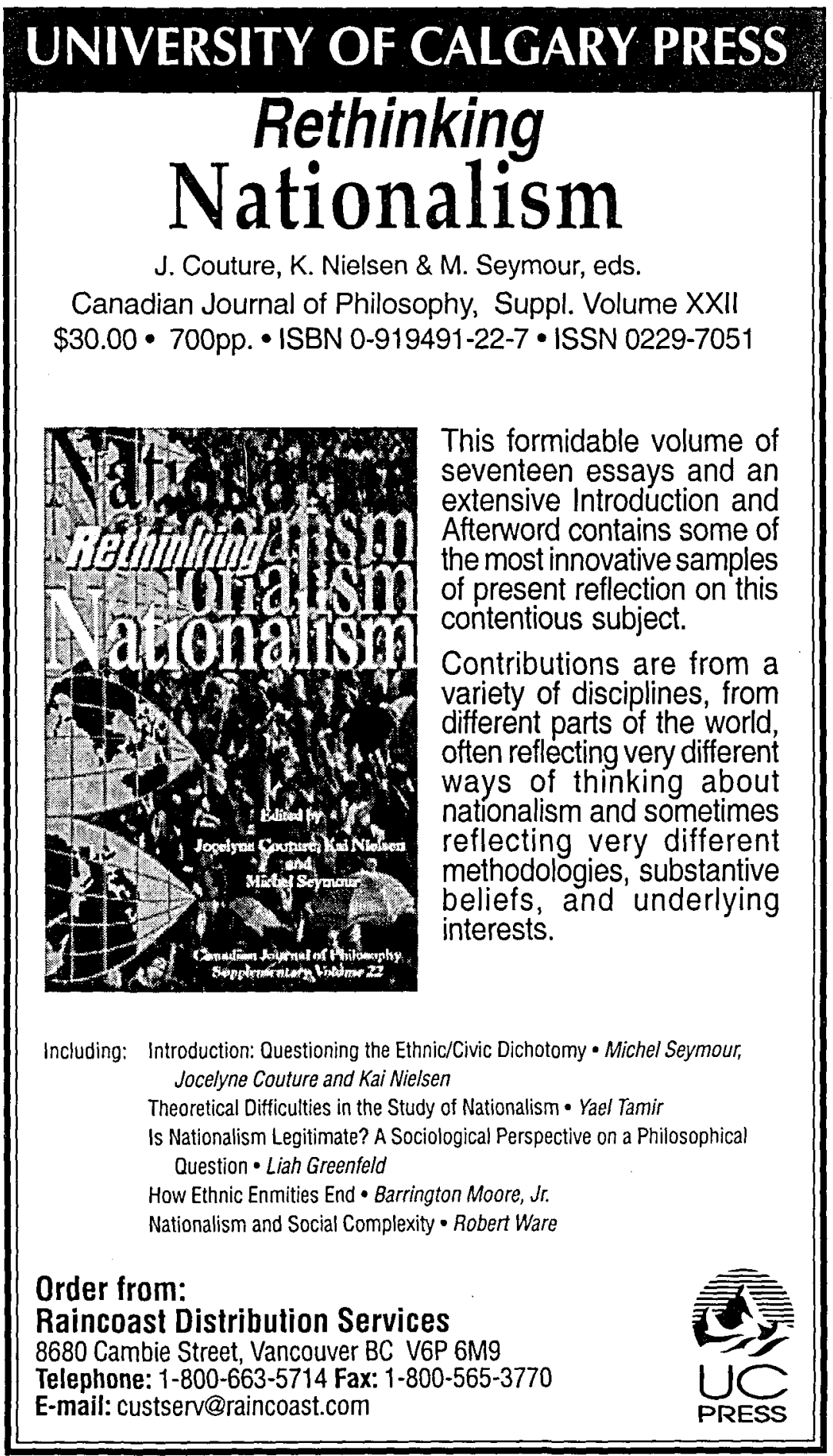




\section{UNIVERSITY OF CALGARY PRESS}

\section{On the Relevance of Metaethics}

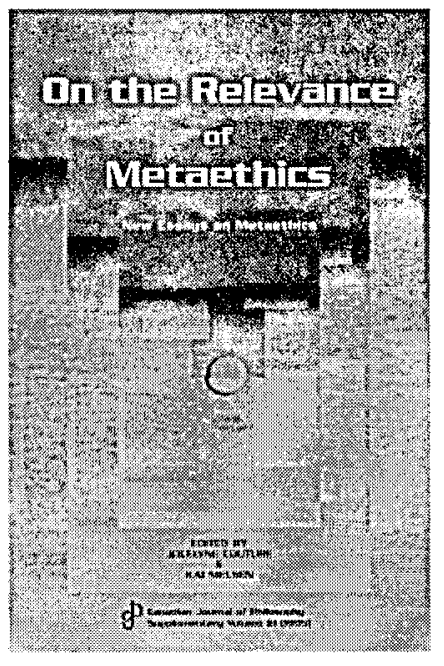

Contents include:

- Jocelyne Couture and Kai Nielsen Introduction: The Ages of Metaethics

- Francis Sparshott

On Metaethics: A Reverie

- Richard B. Brandt

Foundationalism for Moral Theory

- R.M. Hare

Off on the Wrong Foot

- Peter Railton

Made in the Shade: Moral

Compatibilism and the Aims of

Moral Theory

- Jean Hampton

Naturalism and Moral Reasons

- Isaac Levi

Perception as Input and as Reason

for Action
New Essays on Metaethics Jocelyne Couture and Kai Nielsen, editors

Canadian Journal of Philosophy, Supplementary Volume XXI

$\$ 24.00$ (Outside Canada: \$US24.00) ISBN 0-919491-21-9 ISSN 0229-7051 354 pp., $5.5 \times 8.5$ in.

Around mid-century metaethics held centre stage in discussions of moral philosophy in Anglo-American and Scandinavian philosophical environments. During the 1970s, its "foundational" position was challenged by developments within analytic philosophy itself, by a renewal of systematic substantive ethics largely, but not exclusively, of a Rawlsian inspiration and by a reinvigorated interest in substantive moral problems on the part of philosophers. However, as work went on here, philosophers encountered problems concerning the methods of moral reasoning and the structure of justification of moral claims that were recognized to be metaethical. This led to a renewal of metaethics now freed from its previously narrow linguistic focus and aprioristic restrictions.

The essays in this volume contribute both to this renewal and to a continued skeptical probing of the very rationale of moral philosophy.

\section{Order from Raincoast Distribution Services}

8680 Cambie Street, Vancouver BC V6P 6M9

Telephone: 1-800-663-5714

Fax: 1-800-565-3770

E-mail: custserv@raincoast.com

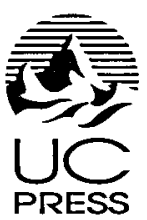




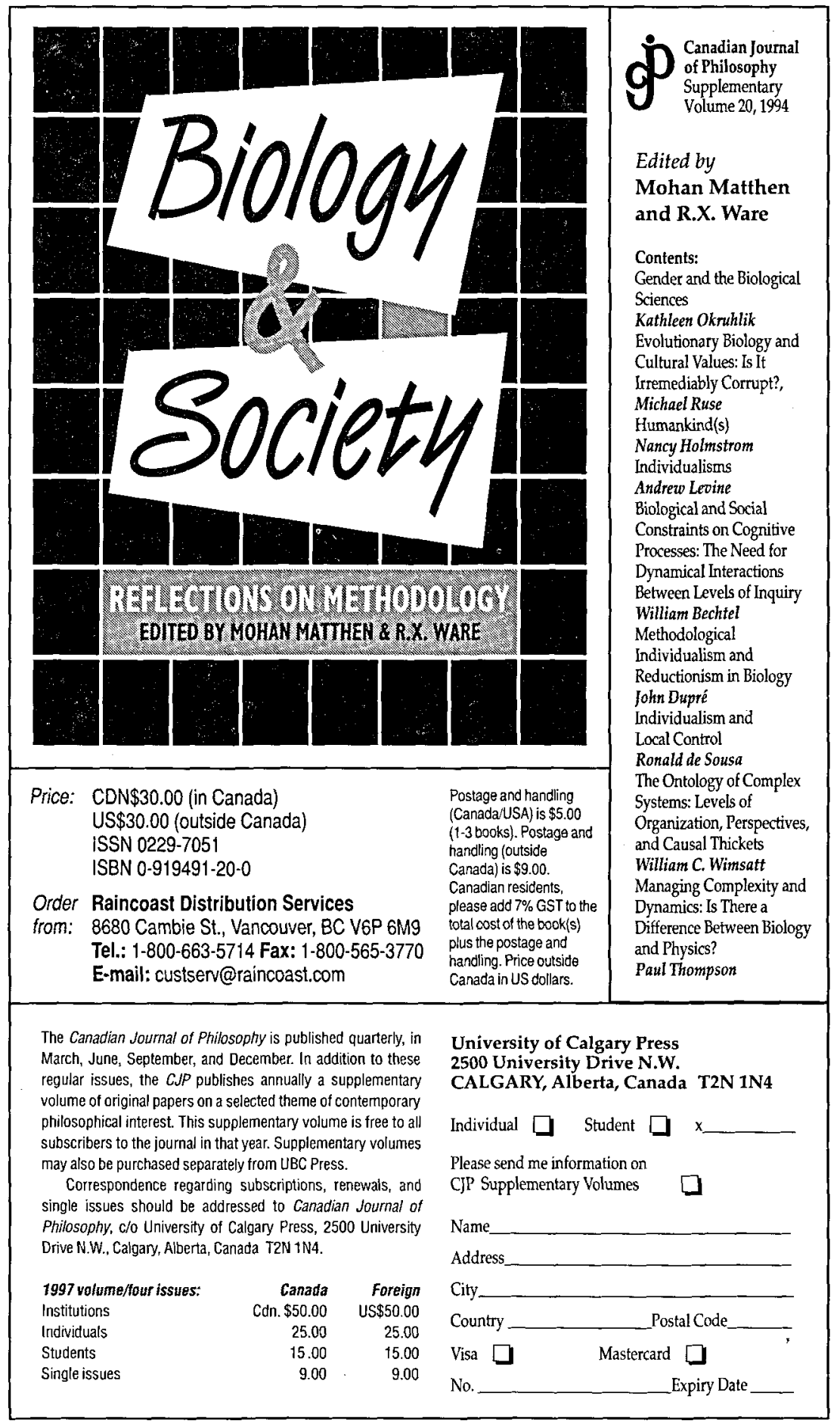




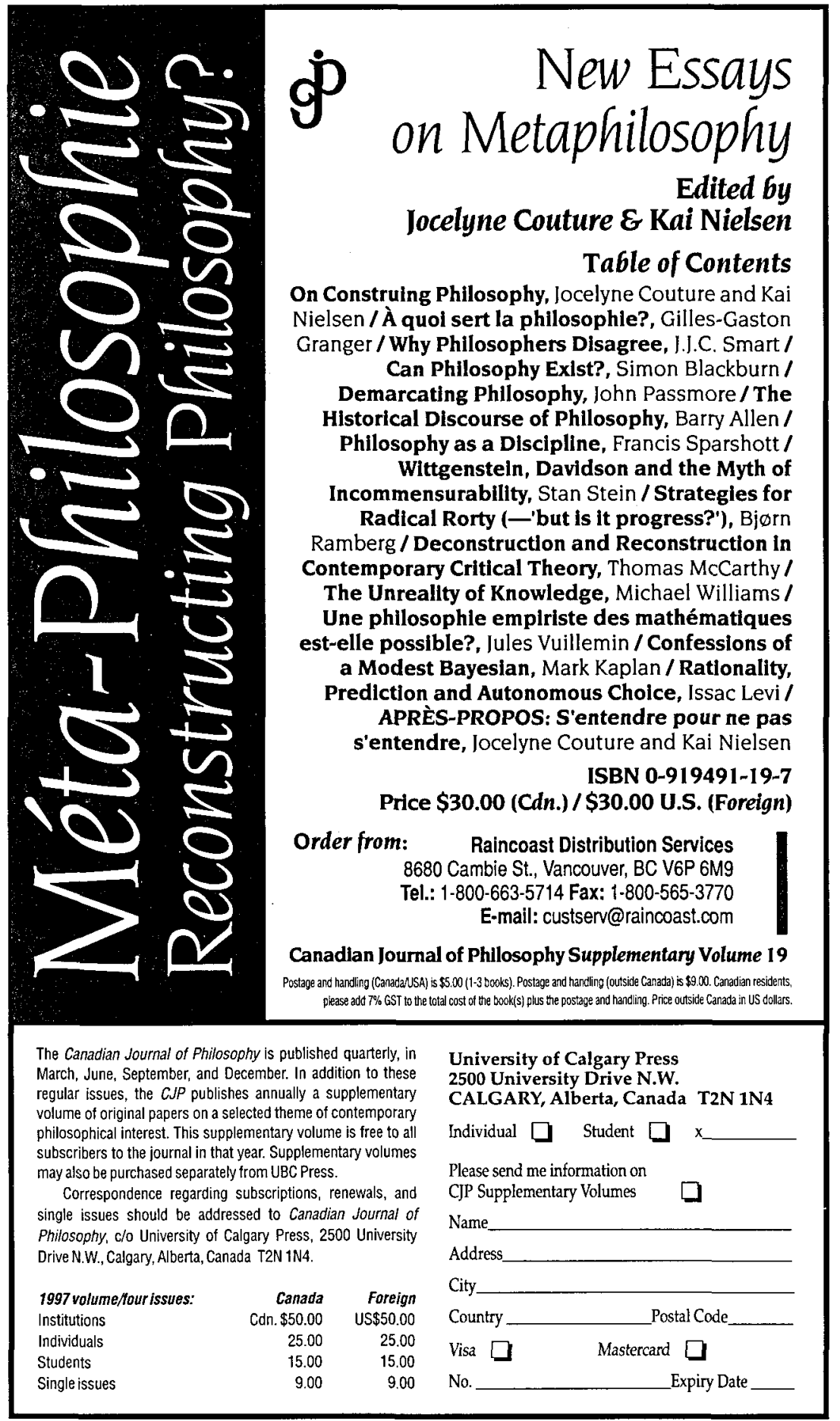




\title{
PHIL OSOPHIQUES
}

REVUE DE LA SOCIEIE DE PHILOSOPHIE DU QUEBEC

Yol. XXY, NN 2

Autom ne 1998

\author{
SOMMAIRE
}

NUMÉRO THÉMATIQUE

\section{LES MODÈLES D'ÉVOLUTION EN ÉCONOMIE ET EN SCIENCES SOCIALES}

ARTICLES sous la direction de Jean Mathiot et Robert Nadeau

Jean Nathiot et Robert Nadeau, Présentation

Maurice Lagueux, Rutionalité et sélection naturelle en économie

Pierre Livet, Jeux évolutionnaires et paradoxe de l'induction rétrograde

backward induction)

Jean Mathiot, Évolution, sélection, information

La question de la convergence.

Alan Kirman, La pensée évolutionniste dans la théorie économique néoclassique

Roger Cornu, Évolution et processus configurationnel chez Norbert Elias

Robert Nadeau, L'évolutionnisme économique de Friedrich Hayek

Alonnement-adhésion

Un abonnentent à Philosophiques, organc officicl de la Société de philosophie du Québec, vous procure automatiquement une adhésion à la SPQ, ainsi qu'un abonnement gratuit au Bulletin de la Société de philosophie du Québec.

STATUTS TARIFS

Étudiant $30,00 \$$

Individuel $50,00 \$$

Socićté de philosophie du Québec

Case Postale \#1370.Place Bonaventure

Montróal (Québec) Canada $\mathrm{H} 5 \mathrm{~A} 1 \mathrm{H} 2$ 


\section{THE MONIST}

AN INTERNATIONAL JOURNAL OF GENERAL PHILOSOPHICAL INQUIRY

JANUARY $1999-\quad$ VOL. 82, NO. $1 \bullet \quad$ SINGLE ISSUE, US \$9

\section{PHILOSOPHY OF COMPUTER SCIENCE}

ADVISORY EDITOR: GIUSEPPE LONGO

ARTICLES

Timothy R. Colburn

JAMES H. FETzER

VINCENT SCHÄCHTER

Peter Wegner

WILLIAM J. RAPAPORT

Oron Shagrir

WiLfried Sieg \&

JOHN BYRNES

G. Graham White
Software, Abstraction, and Ontology

The Role of Models in Computer Science

How does Concurrency Extend the Paradigm of Computation?

Towards Empirical Computer Science

Implementation is Semantic Interpretation

What is Computer Science About?

An Abstract Model for Parallel Computations:

Gandy's Thesis

Simulation, Theory, and Cut Elimination

Editor: Barry Smith, State University of New York at Buffalo

Single issues, \$9 postpaid. Annual subscription: institutions, US \$48; individuals, US \$25; make checks payable to THE MONIST, Box 600, La Salle, IL 61301. 


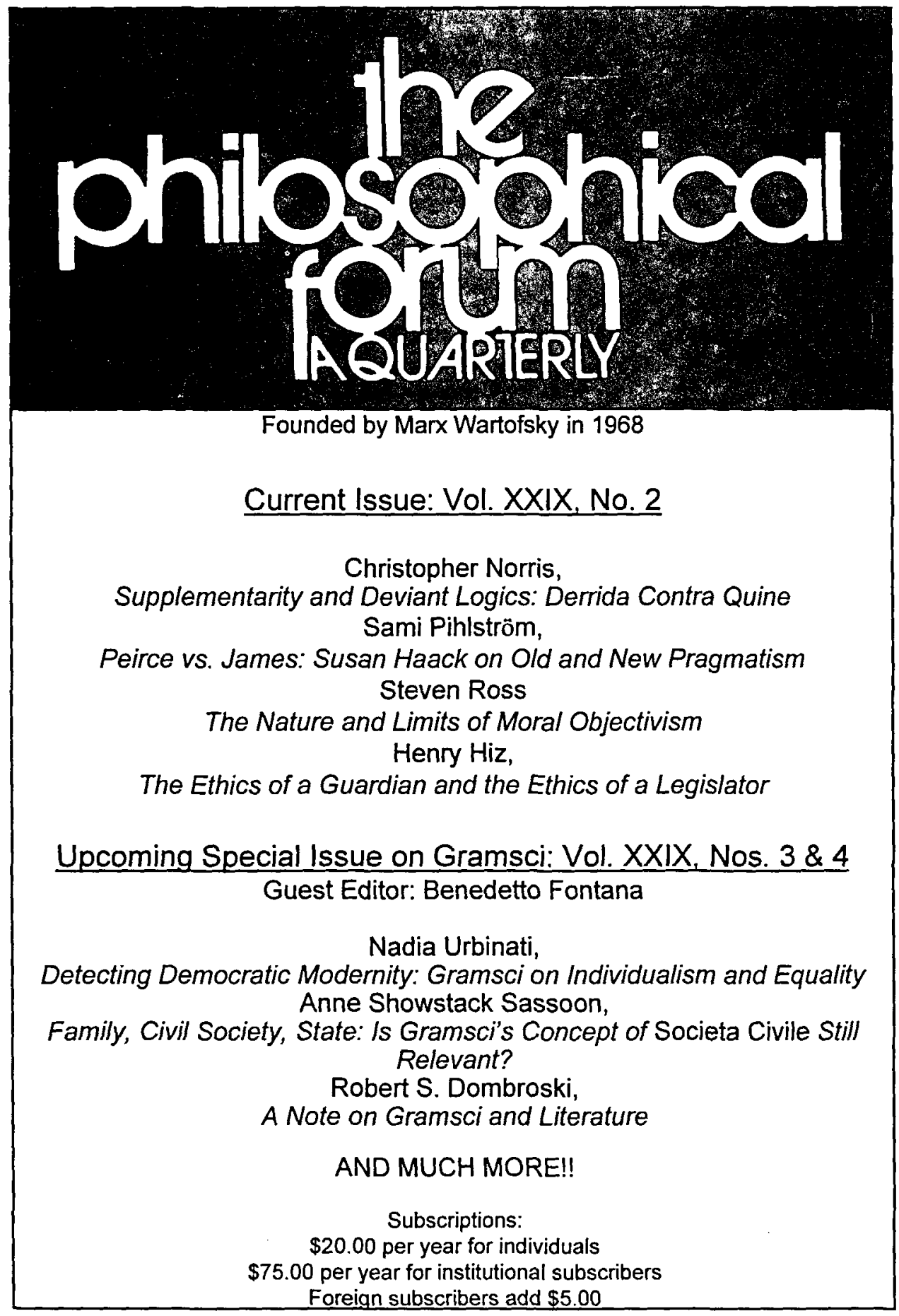




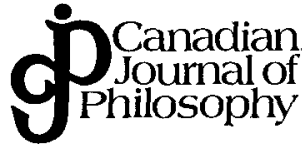

Acknowledgements/ Remerciements
Canadian Journal of Philosophy is published with the aid of a grant from the Social Sciences and Humanities Research Council of Canada.

La publication du Canadian Journal of Philosophy est rendue possible grâce à une subvention du Conseil de Recherches Humaines du Canada.

Canadian Journal of Philosophy wishes to thank the University of Lethbridge for its generous support for the editorial administration of the journal.

Canadian Journal of Philosophy tient à remercier l'Université de Lethbridge de l'aide généreuse qu'elle apporte à la gestion de sa rédaction.

Canadian Journal of Philosophy is grateful for past support from its originating sponsor, the Canadian Association for Publishing in Philosophy.

Canadian Journal of Philosophy désire exprimer sa gratitude à l'Association Canadienne des Publications en Philosophie qui l'a aide par le passé. 